\title{
The Role of Leadership In Improving Employee Discipline
}

\author{
Astry Conny Simorangkir, ${ }^{1)}$ Betty A. S. Pakpahan, ${ }^{2)}$ Sandy Ariawan ${ }^{2)}$ \\ ${ }^{1}$ Postgraduate Student of State Institute for Christian Studies (SICS) Tarutung \\ ${ }^{2}$ Lecturer of State Institute for Christian Studies (SICS) Tarutung
}

\begin{abstract}
Discipline is very important because discipline plays a role in creating disciplined and productive employees. Discipline means carrying out its responsibilities in accordance with office regulations, thus employees will become more productive and able to work effectively and efficiently. One of the factors that affect the discipline of work is the example of the leader, the example of the leader is very instrumental in determining the discipline of employees, because the leadership is used as an example and role model by his subordinates. The purpose of this study was to analyze the influence of leadership on work discipline. In this quantitative research, researcher gave five alternative answers to respondents using a scale of one to five. The population in this study was employees at the State Minister for Cooperatives, Small and Medium Enterprises, Industry and Trade of North Tapanulli Regency as many as 30 people under the leadership of echelon 3. The $R$ Square value of 0.744 means that 74,4\% of employee work disciplinary variables $(Y)$ can be explained by leadership (X). While the remaining 25,6\% can be explained by other variables that were not studied in this study. Based on the results of the analysis of this study where the leadership plays a role in the discipline of employees' work, this is because good leadership is one of the important factors in the process of disciplining employees' work. Leadership can affect employee discipline and result in the form of work requirements that employees will carry out. If the leadership in the company or organization is good and has the ability to influence or control its employees in carrying out office tasks then the work discipline will be improved as expected by the company.

Keywords: Leadership, Disciplin, Role of Leadership, Improving Discipline
\end{abstract}

\section{INTRODUCTION}

Discipline is very important for the growth of the organization, used primarily to motivate employees to be able to discipline themselves in carrying out work both individually and in groups. In addition, discipline is useful to educate employees to comply with and enjoy existing regulations, procedures, and policies, so as to produce good performance. Disciplinary is "the most important function of"Human Resource Management operative"because the better employee discipline,"the higher the work performance that can be achieved."Without good employee discipline, "it is difficult for the company's organization to achieve optimal results (Wang, 2019). “

Discipline is very important because discipline plays a role in creating disciplined and productive employees. Discipline means carrying out its responsibilities in

125 | Correspondence regarding this article to:

Astry Conny Simorangkir, Postgraduate Student of State Institute for Christian Studies (SICS), Tarutung

Email: astrysimorangkir@gmail.com 
accordance with office regulations, thus employees will become more productive and able to work effectively and efficiently. In addition, discipline is also able to advance and improve the reputation of the organization. One of the factors that affect the discipline of work is the example of the leader, the example of the leader is very instrumental in determining the discipline of employees, because the leadership is used as an example and role model by his subordinates (Liu \& Hallinger, 2018). Leaders must set a good example, good discipline, honesty, fair, and in accordance with the word with deeds. With a good example of leadership, the discipline of subordinates will be good. If the example of the leader is not good (less disciplined), the subordinates will also be less disciplined.

Discipline is the awareness and willingness of a person to adhere to all applicable corporate regulations and social norms. Discipline must be enforced within a corporate organization. "Without the support of good employee discipline, it is difficult for the company to realize its goals. "So, discipline is the key to a company's success in achieving its goals (Shengnan \& Hallinger, 2020)."Leadership is the activity or art of influencing others to cooperate based on the person's ability to guide others in achieving the group's desired goals (Liou \& Liang, 2020).

The existence of the leadership has a huge influence on the progress and development of the organization it leads. Leaders must be able to pay attention and supervise employees in order to work with discipline without being authoritarian (Spector et al., 2014). A leader must be able to influence the behavior of his employees, recognize the individual qualities of his employees and have the ability to awaken the emotional and rational forces of his employees. In addition, leaders must inspire and have broad insights and have leadership talents such as in providing guidance, direction and supervision, obtaining advice, making it easier for new employees to adapt or adjust and instill a sense of discipline to their subordinates. Therefore, to carry out the discipline of work required someone who is firm and able to enforce the discipline of work (Ariawan \& Malang, 2020).

In connection with the explanation above, a study was conducted on one of the Departments engaged in services, namely the State Minister for Cooperatives, Small and Medium Enterprises, Industry and Trade North Tapanuli Regency. The main task of the 
Office of Cooperatives, Small and Medium Enterprises, Industry and Trade of North Tapanuli Regency is to lead, formulate, organize, foster, control, coordinate, and account for the technical preparation and implementation of regional policies in the field of human resources development apparatus. One indicator to see the discipline of employee work is the list of employee attendance.

As already explained on the discipline of work civil servants, some of the rules include the obligation to enter work, the addition of the provision of obligation to achieve work targets, give penalties to employees who violate the rules, and so forth. To increase the spirit of work, foster good cooperation, direct and encourage subordinates, the leaders need to understand the factors of human behavior. The way the leadership in influencing its subordinates is one of them by realizing and enforcing the discipline of work. In realizing the work discipline of the employees, there is a need for the imposition of sanctions or penalties. However, it is not enough with that alone, but also the leadership must pay attention to the level of welfare of its employees as it relates to employment relationships or facilities provided (Kim et al., 2020). The purpose of this study was to analyze the influence of leadership on work discipline.

\section{METHOD}

In this quantitative research, researcher gave five alternative answers to respondents using a scale of one to five. The population in this study was employees at the State Minister for Cooperatives, Small and Medium Enterprises, Industry and Trade of North Tapanulli Regency as many as 30 people under the leadership of echelon 3. A simple linear regression analysis was used to determine the magnitude of the relationship and the influence of an independent variable $(\mathrm{X})$ on a dependent variable $(\mathrm{Y})$. To obtain more targeted results, the researchers used the help of SPSS (Statistical Package for the Social Sciens) software with the formula: $Y=a+b X+e$.

Description:

$\mathrm{Y}=$ work discipline

$\mathrm{a}=$ Constant

$\mathrm{b}=$ Regression Coefficient

$\mathrm{X}=$ leadership role

$\mathrm{e}=$ Default error 


\section{RESULT AND DISCUSSION}

It was stated that discipline is an attitude of conduct and actions in accordance with the rules of the company both written and unwritten. Another definition is expressed in the Websters New Dictionary which states that Discipline is: exercises that develop self-control, character or circumstance as well as regular and efficiency; results of exercises similar to orderly behavior self-control; acceptance or submission to power and control; punitive or correcting treatment; a branch of science (Liou \& Liang, 2020). Work discipline is a tool that managers use to change a behavior and as an effort to raise awareness and willingness of a person to obey all applicable company regulations and social norms. The understanding of work discipline put forward by some experts can be concluded that the discipline of work is the attitude of awareness, willingness and willingness of a person in complying with and adhering to the rules and social norms that apply in the surrounding environment.

Various disciplines are:

a. Preventive Discipline; It is an activity that is carried out to encourage employees to follow various standards of rules, so that misappropriation can be prevented.

b. Corrective Discipline; Activities are taken to deal with violations of the rules that try to avoid further violations. Corrective activities are often a form of punishment.

c. Progressive Discipline; The activity provides harsher penalties for repeated violations.

Discipline is the awareness and willingness of a person to adhere to all applicable corporate regulations and social norms (Liu \& Hallinger, 2018). The indicators are as follows:

a. Effective use of time; Punctuality in carrying out tasks, time savings in carrying out tasks.

b. Compliance with the established regulations; Adherence to working hours, obedience to leadership, adherence to working procedures and methods.

c. Responsibilities in work and duties; Doing the work according to the plan, evaluating the results of the work, courage accepts the risk of error.

Basically many factors that affect the level of discipline of employees in an organization, including:

a. Objectives and abilities; Objectives and abilities influence the level of discipline of employees. The objectives achieved must be clear and ideally set and challenging enough for the ability of employees.

b. Leadership example; It is very instrumental in determining the discipline of employees because the leadership is used as an example and role model by his subordinates. Leaders 
must set a good example, good discipline, honesty, fair, and in accordance with the word with deeds.

c. Repayment; Retribution also affects the discipline of employees because the reply will provide satisfaction and love of employees to the company / work.

d. Justice; Justice contributes to the realization of employee discipline because of the ego and human nature that always feel itself important and ask to be treated the same as other human beings.

e. Inherent supervision; Inherent supervision is the real and most effective action in realizing employee discipline. With inherent supervision means the supervisor must actively and directly supervise the behavior, morals, attitudes, work passions, and work achievements of his subordinates.

f. Punitive sanctions; Punitive sanctions play an important role in maintaining employee discipline. With harsher penalties, employees will be increasingly afraid of violating the company's regulations, attitudes, and reduced employee disciplinary behavior.

g. Assertiveness; The assertiveness of the leadership in taking action will affect the discipline of employees. Leaders must be courageous and decisive, acting to punish employees if they violate the rules in accordance with the sanctions that have been set.

h. Humanitarian relations; Harmonious humanitarian relations among fellow employees contribute to creating good discipline in a company. Relationships that are both vertical and horizontal consisting of direct single relationship, direct group relationship, and cross relationship should be harmonious (Wang, 2017).

The most difficult task for a boss is how to properly enforce work discipline. If an employee violates disciplinary rules, such as being too often late or ditching work, fighting, dishonesty or other behavior that can damage the smooth work of a part, the supervisor must intervene. Such mistakes must be punished and superiors must strive to prevent such behavior from reoccurring (Ariawan, 2020). There are several ways to enforce work discipline in a company:

a. Discipline must be enforced instantly; Penalties should be imposed as soon as possible after an offence, do not be late, because if it is too late it will be less effective

b. Discipline must be preceded by early warning; Early warning is intended that all employees must properly know exactly which actions are justified and which are not

c. Discipline must be consistent; Consistent means that all employees who commit violations will be punished the same. Do not let exceptions, perhaps for reasons of long tenure, have high skills or because they have a relationship with the boss itself. 
d. Discipline must be impersonal; Superiors should not enforce discipline with feelings of anger or emotion. If there is such a feeling it is good for the boss to wait a few minutes for his anger and emotions to subside before disciplining the employee. At the end of the conversation should be given a positive briefing to strengthen the relationship between employees and superiors.

e. Discipline must be worth it; The punishment is worth it meaning that the punishment is appropriate and in accordance with the offence committed. Not too light and also not too heavy. If the punishment is too light, it will be considered trivial by the offender and if it is too severe it may cause anxiety and degrade achievement.

Coefficient of determination $\left(\mathrm{R}^{2}\right)$ testing is used to measure the proportion or percentage of a model's ability to describe bound variables. The coefficient of determination ranges from zero to one $\left(0 \leq R^{2} \geq 1\right)$. If $R^{2}$ is getting larger (close to one), then it can be said that the influence of a free variable $(\mathrm{X})$ is large on a bound variable $(\mathrm{Y})$. This means that the model used is getting stronger to explain the influence of free variables on bound variables and vice versa.

Table 1. Model Summary ${ }^{\mathrm{b}}$

\begin{tabular}{|c|r|r|r|c|}
\hline Model & $\mathrm{R}$ & R Square & Adjusted R Squar & $\begin{array}{c}\text { Std. Error of the } \\
\text { Estimate }\end{array}$ \\
\hline 1 & .863 & .744 & .734 & 2.04019 \\
\hline
\end{tabular}

a. Predictors: (Constant), leadership role

b. Dependent Variable: work discipline

Based on Table 1, it can be seen that:

1. $\mathrm{R}=0.863$, means the relationship between the leadership role variable $(\mathrm{X})$ and the disciplinary work of the employee (Y) is strong.

2. The value of $R$ Square of 0.744 means that $74,4 \%$ of employee's work disciplinary variable (Y) can be explained by the leadership role variable (X). While the remaining 25,6\% can be explained by other variables that were not studied in this study.

3. Standard Error of Estimated means to measure variations of predicted values. In this study the standard deviation is 2.04019 The smaller the standard deviation means the better the model.

Leadership in the Office of Cooperatives, Small and Medium Enterprises, Industry and Trade North Tapanuli District has a relatively large influence on the discipline of work. So 
in this case the author can conclude that good leadership is one of the factors that influence in improving employee discipline.

\section{CONCLUSION}

Based on the results of the analysis of this study where the leadership plays a role in the discipline of employees' work, this is because good leadership is one of the important factors in the process of disciplining employees' work. Leadership can affect employee discipline and result in the form of work requirements that employees will carry out. If the leadership in the company or organization is good and has the ability to influence or control its employees in carrying out office tasks then the work discipline will be improved as expected by the company. A leader must be able to be friendly, open, and easy to make friendships based on mutual trust, and respect the opinions of others in order to foster good cooperation in a harmonious and peaceful atmosphere. A leader must also be able to be a creator, motivator and direct his subordinates by creating a new atmosphere and work culture that can spur the comfortableness of employees to work in the company. If the employee is comfortable under the direction of a good leader and there is solid or strong cooperation among them then the discipline in work will increase. Because starting from good employee discipline will create qualified employees, which will reflect an overall performance of the company. The R Square value of 0.744 means that $74,4 \%$ of employee work disciplinary variables (Y) can be explained by leadership (X). While the remaining 25,6\% can be explained by other variables that were not studied in this study.

\section{REFERENCES}

Ariawan, S. (2020). Etika Guru Pendidikan Agama Kristen. Pena Persada.

Ariawan, S., \& Malang, S. (2020). Building Critical Thinking in Covid-19 Pandemic Era: Impossible or I am Possible? International Research Journal on Advanced Science Hub. https://doi.org/10.47392/irjash.2020.49

Ariawan, S. (2021). BEWARE OF THE DECLINE IN PEDAGOGICAL COMPETENCE OF TEACHERS DURING THE COVID-19 PANDEMIC: REFLECTING ON DIVINE CALLING. Jurnal Teologi, Misi Dan Pendidikan Agama Kristen, 1(01), 60-71. Retrieved from https://jurnal.sttlintasbudayabatam.ac.id/index.php/bahtera/article/view/8

Kim, M. K., Wang, Y., \& Ketenci, T. (2020). Who are online learning leaders? Piloting a leader identification method (LIM). Computers in Human Behavior. https://doi.org/10.1016/j.chb.2019.106205 
Liou, D. D., \& Liang, J. “Grace.” (2020). Toward a Theory of Sympathetic Leadership: Asian American School Administrators' Expectations for Justice and Excellence. Educational Administration https://doi.org/10.1177/0013161X20941915

Quarterly.

Liu, S., \& Hallinger, P. (2018). Principal Instructional Leadership, Teacher Self-Efficacy, and Teacher Professional Learning in China: Testing a Mediated-Effects Model. Educational Administration https://doi.org/10.1177/0013161X18769048

Quarterly.

Shengnan, L., \& Hallinger, P. (2020). Unpacking the effects of culture on school leadership and teacher learning in China. Educational Management Administration and Leadership. https://doi.org/10.1177/1741143219896042

Spector, J. M., Merrill, M. D., Elen, J., \& Bishop, M. J. (2014). Handbook of research on educational communications and technology: Fourth edition. In Handbook of Research on Educational Communications and Technology: Fourth Edition. https://doi.org/10.1007/978-1-4614-3185-5

Wang, Y. (2017). Education policy research in the big data era: Methodological frontiers, misconceptions, and challenges. Education Policy Analysis Archives. https://doi.org/10.14507/epaa.25.3037

Wang, Y. (2019). Pulling at Your Heartstrings: Examining Four Leadership Approaches From the Neuroscience Perspective. In Educational Administration Quarterly. https://doi.org/10.1177/0013161X18799471 